\title{
A Review of Professor Paul H. Fry's book Theory of Literature
}

\author{
Dr. Mutasem T. Q. Al-Khader \\ Associate ProfessorAl-Quds Open University \\ P.O. Box (65) TulkarmPalestine Authority Palestine
}

\begin{abstract}
Book Description:Theory of Literature by Professor Paul H. Fry, Published in New Haven and London on April 24th 2012 by Yale University Press, paperback, 400 pages, 18\$, ISBN 978-0-300-1808-1.

Paul H. Fry is a William Lampson Professor of English at Yale University and the author of numerous books and articles.

My review is somehow lengthy because of the many literary theories that are surveyed throughout Fry's book. This book is highly recommended for readers who would like to learn about modern literary theory, which started in the twentiethcentury. In addition to Fry's discussion of literary theory, he attempts to answer disputed questions such as: what is the definition of literature, how is it created, how can it be understood, and what is its purpose?

Fry explains the main ideas of every critical theory and gives his own opinion about these theories in a logical, convincing manner. It is remarkable how Fry successfully uses a very simple lyrical song, "Tony the Tow Truck," to introduce questions about literary theories and to then answer them.In his discussion of each literary theory, he mentions at least one article by one of the major writers of that theory to give his readers a full, comprehensive understanding about that theory.

The book is divided into five parts starting with a Prefaceand a comprehensive
\end{abstract}

\section{Introduction}

In Chapters 1 and 2, which shows how our outlook toward literature changedover the course of timefrom thinking that literature is formed by language, to the idea that literature is formed by the human psyche, to the idea that literature is formed by social, economic, and historical forces. These different outlooks produced the various literary theories that emerged in the twentieth-century.

The second part of the book, First Reflections on Interpretation and Reading, discusses hermeneutics, which is based on the reader's engagement with the text and not with its author. Regarding hermeneutics,Gadamer seems to impose on us a "traditional canon," and Iser seems to impose on us an "innovative canon."

The third part, Text and Structure, contains a survey of traditional literary criticism, the New Criticism and other western Formalisms, which depend on reason and understanding of the text's unity, coherence and self-sufficiency. The main problems faced by both Richards and Empsonare that the formerchanged his terminology, while the latter rarely concerns himself with the entirety of a text. Russian Formalists who are influenced by Darwin's determinism and Marx's class struggle are characterized by the "determination of meaning" and are exclusively concerned with the way in which literature is conceived. They believethat history and social history produce literature.In contrast to some other theories, Semiotics and Structuralismdo not havea direct bearing on literary study, and yet they have influenced that field enormously. Saussure's version of Semiotics considered language as a "system of signs" and that later developed into Structuralism.In Linguistics and Literature, a detailed account is given of "synchrony," which is the norm of any historical moment, and "diachrony,"which is the change caused by external pressure to the structure of language conventions. Chapter 10 discusses Derrida's departure from Structuralism and the birth of Deconstruction after his article, Structure, Sign, and Play, in which he explains the correlations between the "signified" and "signifier" and between "difference" and "différence." Deconstruction is the dismantling of the grounds whereby we suppose that our thinking can be derived from one or another definite concept.Although a believer in Deconstruction, Paul de Manis unlike Derrida because he believes that deconstruction of the text occurs from within and not from without. Thus, De Man denies the existence of any reality outside the text. For him,literature is unlike everyday language because it is the "only knowledge free from the fallacy of unmediated expression" and it is a "perpetual denial of its referentiality."

The fourth part, Author (Reader) and Psyche, Freud and Fiction,is a discussion of the correlations between consciousness, the unconscious, metaphor and metonymy and the death wish in the text. In Jacques Lacan in Theory, Lacan"does not believe in a suitable ending" including within the text because we will never have what we desire. Of the raw materials of the "id" in the unconscious, the ego should arise as the capacity of human consciousness to grow into maturity through the sublimation of libidinal drive. Chapter 14, Influence, 
discusses Boom and Eliot,who are influenced by critical traditions. Bloom's most important contribution to literary theory is the set of ideas that make him an important literary historiographer.He is concerned with the crisis concerning one's orientation to other texts. Eliot believes that a mutual relationship exists between traditions and individual talents, but he insists on "self-effacement" and the recognition that the collective mind of Europe is more important than one's own mind. The Postmodern Psycheis a discussion of the psychological genesis of the text and its correlations with politics and the social psyche. Postmodernism is an eclectic orientation to the past. Žižekposits that the"rhizomatic" mode of thinking, which is "radically decentering," leads to fascism and ultimately to democracy, while Deleuze argues that this decentering leads to many "simultaneous concepts" instead of a single governing concept. Thus, several points of incommensurability exist in the text.

The fifth part, The Social Context.In The Social Permeability of Reader and Text,Bakhtin and Jaussargue that literary and social voices are inseparable, but Bakhtin's primary concern is with the outside world that produces a text, and Jauss'sprimary concern is the world in which a text is received. The Frankfurt School of Critical Theory is influenced by Marx, who influenced many critics with his view that the work of art is experiencing the work ideologically as a commodity, which leads to giving up realism for formalism and then for utopian romance.Theodor Adornoargues against the "high modernist aesthetic"because the delight in the moment and the gay façade become an excuse for absolving the listener from thinking historically. Benjamin posits that we receive texts as we receive our dwellings: in a state of "constructive distraction."Jameson's The Political Unconscious is discussed in Chapter 18. Folktales and fairy tales are not just symbolic fantasies, but rather social gestures of the insuperable contradictions and the impossibility of resolutions. However, these contradictions and conflicting modes of production contain laws, causes and dynamics that we need to understand, as they bring about cultural revolution. The New Historicism is a movement that swept the academy in the late 1970s, through the 1980s into the 1990s. History dictates what literature can say in a given epoch. New historicists followed Foucault in his interest in the distribution of power,which is different from ideology. These scholars argue that the real world shapes itself through language. McGannis unique in this movement because he does not place as much emphasis on the reciprocity of history and literature. Gender in The Classical Feminist Traditionis one of the factors underlying determination of identity and consciousness. "Gynocriticism" is not so much concerned with men's treatment of women in fiction as it is with the place of women as writers in literary history. Virginia Woolf argues that, in the moment when one no longer thinks of being male or female, this advanced mind no longer writes a man's sentence or a woman's sentence. In African American Criticism, a sufficient détente has been achieved since the 1980s, andAfrican American literary theory moves forward with the issue of identity at its center. Gates' message is to understand one other;accordingly, we must master how to "speak the other's language without renouncing our own."In Postcolonial Criticism, Edward Said and HomiBhabharepresent stages of postcolonial discourse. They present their ideas about postcolonial studies despite the fact that colonialism is still occurring. Said believed that "East" and "West" are not always descriptive terms because there is noeast without the west, but the outlook toward the third world is a component of "Eurocentrism." Literature of the East contributed greatly to the West from the Arabian Nights to Rubaiyat of Omar Khayyam. Both Said and Bhabharevolt against Western literary theoryfrom within by making use of its Structuralism and Deconstructionism. For Said, hegemonic opinions construct the postcolonial world and simultaneously reinforce the authority of those who generate the prevailing opinion. Bhabhaopenly criticizes traditional "binarism,"which is a type of a deconstruction of postcolonialism. Queer Theory and Gender Performativity is about both Foucault and Butler, who posits that the "concept of sexuality" continues to elude us because sexuality cannot be known in a "binary" relation to another concept. Foucault sees sexuality as the effect of power-knowledge, while Butler sees it as the effect of performancemanifested through psychic excess. Foucault clarifies the intersection between "deployment of alliance," that is, the social aspects related to sexuality secured by laws and restricts, and the "deployment of sexuality," which refers to experienced bodily pleasure. The Institutional Construction of Literary Studyinvolves the way in which identity is constructed in literature. The sum of critical devices is the sum of communally accepted and recognized contributions to the building of what has been regarded as literature for interpretive communities over time. Fish believes that "interpretation is not the art of construing but the art of constructing." Interpreters do not decode poems; theycreate them. Guillory's own deepest commitment is to the great works, mainly the classics. He believes that history continuously changes canons because writers of modern languages and literature have radically thinned out this canon to make room for themselves.

The sixth part, Theory Con and Pro.In The End of Theory? Neo-Pragmatism, Steven Knapp and Walter Benn Michaels are neo-pragmatists whose theory is increasingly influential in literary academic thinking because it is materially grounded and reflects the dynamics of social interchange and that the deployments of language are interactive. If a person would like to interpreta text, he simply gets on with the business of thinking and doing. It is wrong to "cobble together some theoretical justification" for what one is doing. Thus,Knapp and 
Michaels are against hermeneutics, that is, the search for rationales for interpretation, because a reader can know the meaning of a word but not the intention of a word.

\section{In Conclusion:}

Who Doesn't Hate Theory Now? Theory is interested in the way meaning is impeded. Indeed, this section allows us to draw our own conclusions, as it were, and reminds us that there are some limits or reservations best kept in mind while thinking through problems or interpretation and meaning.

The end of the book contains an appendix of Passages Referenced in the Book followed by Stefan Esposito's article The Varieties of Interpretation: A Guide to Further Reading in Literary Theory. 